\title{
Failure to isolate Helicobacter pylori from stray cats indicates that $H$. pylori in cats may be an anthroponosis - an animal infection with a human pathogen
}

\author{
F. A. K. EL-ZAATARI*†, J. S. WOO†, A. BADR†, M. S. OSATO $\dagger$, H. SERNA**, \\ L. M. LICHTENBERGER**, R. M. GENTA* $+\$ \S$ and D. Y. GRAHAM ${ }^{*}+\|$ \\ *Inflammatory Bowel Disease Laboratory, Veterans Affairs Medical Center, Departments of + Medicine, \\ $\$$ Pathology, \$Microbiology and Immunology, \|Division of Molecular Virology, Baylor College of Medicine and \\ **Department of Physiology and Cell Biology, University of Texas Medical School, Houston, TX, USA
}

\begin{abstract}
The recent isolation of Helicobacter pylori from cats obtained from a commercial supplier has potentially important public health implications. The present study investigated whether $H$. pylori infection was common in stray cats. Twenty-five cats were examined for the presence of $\boldsymbol{H}$. pylori by histological examination, culture and two polymerase chain reaction (PCR) assays. Histologically, the gastric biopsy specimens from all cats showed large spiral organisms typical of $\boldsymbol{H}$. felis and not $\boldsymbol{H}$. pylori. Samples from 23 cats yielded bacterial growth and two had no growth. Colonies grossly similar to $H$. pylori were tested for catalase, oxidase, urease and Gram's stain reactions. None was $H$. pylori. All samples tested as positive by the Helicobacter 16S rRNA genus-specific PCR assay and only six cats and a mouse stomach infected with $H$. heilmannii gave positive results with the adhesin subunit $A$ (hpaA)-specific PCR assay, which is consistent with either $H$. pylori or $H$. heilmannii. The helicobacters identified in these samples by PCR were not cultivable and hence were probably $H$. heilmannii. $H$. pylori infection is uncommon in stray cats and owning pet cats should not be a threat to public health in relation to $H$. pylori infection.
\end{abstract}

\section{Introduction}

Helicobacter pylori infection is a major health problem as it is the cause of peptic ulcers and plays a major role in the development of gastric cancer [1]. Although current evidence suggests that the natural reservoir for infection is man, the primary route of transmission is unknown. H. pylori has been isolated or detected in faeces, saliva, dental plaque and, recently, in water [2-8]. The available data are consistent with faecaloral, oral-oral or a common environmental source as possible mode(s) of transmission [8-14]. Understanding the mode(s) of transmission of $H$. pylori is essential for developing public health measures to control the spread of infection.

Recently the search for reservoir hosts and an animal model for $H$. pylori infection led to the isolation of the organism from the gastric antrum and corpus of

Received 24 June 1996; revised version accepted 20 Sept. 1996.

Corresponding author: Dr D. Y. Graham. domestic cats obtained from a single commercial source of research animals $[15,16]$. The possibility that cats may be a zoonotic source of $H$. pylori infection in man was suggested. This development is significant with regard to public health implications; cats could represent a natural reservoir that transfers $H$. pylori to man. This study was designed to evaluate the prevalence of $H$. pylori infection in stray cats. Several procedures were used, including biochemical, histological and cultural analysis to detect $H$. pylori and differentiate it from other Helicobacter spp. To confirm the identity of the organism, two recently developed PCR assays were used; one based on the $H$. pylori $16 \mathrm{~S}$ rRNA sequence, is Helicobacter-genus specific and the other is based on the $H$. pylori adhesin subunit A (hpaA) encoding gene.

Materials and methods

Animals and gastric specimens

Twenty-five stray cats scheduled to be killed by the Harris County Animal Control Center were studied. 
Ages ranged between 4 weeks and 30 months. All cats were healthy. Gastric tissues were obtained immediately after death. The stomach was exposed by a midline abdominal incision and was removed by transection of the distal oesophagus and the proximal jejunum. It was opened along the greater curvature. The stomach mucosa was not rinsed to keep the bacteria attached to the mucosal surface. Sharp cut dissection was used to obtain long samples of mucosa, submucosa and muscularis propria. Several specimens were obtained from the fundus, body, antrum and duodenum of each cat's stomach. Two biopsy samples from each site of the stomach were placed separately in cysteine medium containing glycerol $20 \%$ and frozen at $-70^{\circ} \mathrm{C}$ until analysed by culture and PCR. Additional biopsy samples from each site were fixed in buffered formalin $10 \%$ for histological analysis.

A snap frozen mouse stomach infected with $H$. heilmannii was a gift from $\mathrm{Dr}$ A. Lee, University of New South Wales, Sydney, Australia. The stomach was obtained from a BALB/c mouse bred in a specific pathogen-free environment before infection.

\section{Culture and histological analysis}

The culture procedure used routinely in this laboratory to isolate $H$. pylori from human gastric biopsies was applied to these feline biopsy samples $[17,18]$. The tissue samples were thawed at room temperature, then dissected into smaller pieces. Multiple, representative sections of the stomach were taken for culture. The tissues were minced, then ground between the frosted ends of two sterile microscope slides; c. $50 \mu 1$ of cysteine medium were used to resuspend the ground tissues for transfer to plated media and $25-\mu 1$ volumes of the tissue suspension were used to inoculate one selective and one non-selective horse blood agar plate (HBA). The horse blood agar contained Brain Heart Infusion broth (Difco Laboratories, Detroit, MI, USA) with Bacto-agar (Difco Laboratories) $1.3 \%$ and horse blood (Cocalico Biologicals Inc., Reamstown, PA, USA) $10 \%$. Selective plates were supplemented with amphotericin $\mathrm{B}$, trimethoprim and vancomycin. All plates were incubated at $37^{\circ} \mathrm{C}$ in air with $\mathrm{CO}_{2} 12 \%$ and $100 \%$ humidity for up to 14 days as described previously $[17,18]$. Bacterial growth resembling $H$. pylori was picked and transferred to fresh, nonselective HBA plates. Identification of bacterial isolates as $H$. pylori was based on the results of the Gram's stain reaction, cell morphology and positive reactions for catalase, urease and oxidase activity. Identification tests for other bacterial isolates were determined by the Clinical Microbiology Laboratory, VA Medical Center, Houston, TX, by standard procedures [19].

For histological examination, each formalin-fixed biopsy sample was processed, oriented on edge, embedded in paraffin and cut in sequential $4-\mu \mathrm{m}$ sections. From each specimen, one slide (usually with
8-12 sections) was stained with haematoxylin and eosin (H \& E), one with periodic acid Schiff (PAS), and one with the Genta stain for the visualisation of Helicobacter spp. Virtually all specimens included surface epithelium and muscularis mucosae. The presence of Helicobacter spp. was assessed morphologically and the results were scored as infected or uninfected based on the presence or absence of the organism.

\section{Nucleic acid preparation}

To prepare nucleic acid from the cat's tissues and the mouse stomach, biopsy samples were processed as described previously [20]. Briefly, each specimen (50$100 \mathrm{mg}$ ) was thawed and washed in sterile saline, then homogenised in $300 \mu 1$ of lysis buffer $(10 \mathrm{~mm}$ Tris$\mathrm{HCl}, 1 \mathrm{~mm}$ EDTA, pH 8.0, $10 \mathrm{~mm} \mathrm{NaCl}$, Triton X-100 $1 \%$, and proteinase $\mathrm{K} 20 \mathrm{mg} / \mathrm{ml}$ final concentration) with a disposable pestle homogeniser (Kontes, Vineland, NJ, USA). After incubation for $3 \mathrm{~h}$ at $55^{\circ} \mathrm{C}$, lysozyme was added to a final concentration of $50 \mathrm{mg} /$ $\mathrm{ml}$ and incubation was continued overnight at $37^{\circ} \mathrm{C}$. The mixture was then boiled for $20 \mathrm{~min}$ followed by multiple extractions with an equal volume of a mixture of phenol:chloroform:isoamyl alcohol (phenol/CIAA; 24:1, v:v) and CIAA, respectively. The nucleic acid templates were ethanol precipitated, dissolved in $100 \mu 1$ of TE (10 mM Tris-HCl, 1 mM EDTA, pH 8.0) buffer, and stored at $-20^{\circ} \mathrm{C}$ until used.

\section{PCR and hybridisation analysis}

The PCR assay of the hpaA adhesin-encoding gene was applied with the same primers - hpa-1 primer (5'GAATTACCATCCAGCTAGCG-3') and hpa-2 primer (5'-GTAACCTTGACAAAACCGGC- $\left.3^{\prime}\right)$ - and conditions as described previously [8]. These primers amplify a 375-bp fragment of the adhesin subunit gene $[8,21]$. To confirm that any product was actually indicative of the presence of a Helicobacter sp., the samples positive with the above assay were also evaluated with a second PCR, a 16S rRNA RT-PCR, as described previously $[8,20,22]$. The two oligonucleotide primers derived from $H$. pylori 16S rRNA and designated HP1 (5'-TGGCAATCAGCGTCAGGTAATG- ${ }^{\prime}$ ) and HP2 (5'-GCTAAGAGATCAGCCTATGTCC- $3^{\prime}$ ) were used in the RT-PCR assay. Ten $\mu 1$ of the extracted DNA from each gastric tissue sample were used as templates in each reaction. Positive and negative controls were also tested in parallel with each assay. The oligonucleotide primers were custom synthesised (Genosys Biotechnologies Inc., Houston, TX, USA).

To improve sensitivity, Southern blots and subsequent hybridisation were performed. The target sequences ( $375 \mathrm{bp}$ and $506 \mathrm{bp}$ amplified from the reference strain H. pylori RD26) generated by both assays were used as probes in Southern blot hybridisations. The probes 
were labeled with digoxigenin-11-dUTP by the hexanucleotide priming technique with the Genius labelling kit following the manufacturer's instructions (Boehringer Mannheim, Indianapolis, IN, USA). For gel and Southern blot analysis, 20- $\mu$ l volumes of PCR samples were electrophoresed through agarose $2 \%$ gels containing ethidium bromide $0.5 \mu \mathrm{g} / \mathrm{ml}$ and photographed under UV light. The amplified fragments were then transferred overnight on to nylon membranes (Hybond-N+; Amersham, Arlington, IL, USA) by the alkaline transfer method with $0.4 \mathrm{~N} \mathrm{NaOH}$ [22]. Hybridisations with digoxigenin-labelled probes were performed with the Genius kit as directed by the manufacturer (Boehringer Mannheim).

\section{Results}

\section{Histology and cultures}

Large spiral organisms morphologically similar to $H$. felis or to $H$. heilmannii (previously known as Gastrospirillum hominis) and not morphologically similar to H. pylori were seen in biopsy samples from all cats. Cultures from 23 of 25 cats showed bacterial growth resembling Pasteurella spp., as well as mycoplasma and other bacteria; two had no growth. Colonies grossly similar to $H$. pylori were selected for further study and tested for catalase, oxidase, urease and Gram's stain. None was $H$. pylori.

\section{Amplification analysis}

The specificity and sensitivity of the hpaA-PCR assay and the 16S rRNA RT-PCR assay has been demonstrated previously $[8,20]$. The expected 375-bp fragment from the hpaA-PCR assay was detected from as few as one bacterium per reaction and the 506-bp fragment from the $16 \mathrm{~S}$ rRNA RT-PCR assay was detected from two bacterial cells/reaction. Samples from all the cats tested gave positive results for Helicobacter by the $16 \mathrm{~S}$ rRNA genus-specific RTPCR assay and samples from six of the cats and the mouse gave positive results by the adhesin subunit $\mathrm{A}$ (hpaA)-specific PCR assay. The specificity of these results was confirmed by Southern hybridisation with the amplified fragments as specific probes (Fig. 1). Taken together with the failure in cultivation, it is likely that positive results by the hpaA-specific PCR assay were due to $H$. heilmannii.

\section{Discussion}

H. pylori is a significant gastro-intestinal pathogen because of its association with digestive diseases in man such as peptic ulcer, gastric cancer and MALT lymphoma [1,23-25]. Experimental animal models are needed to study the role of the micro-organism in these diseases and the mechanism(s) of disease formation and prevention. During the process of development of

\section{I}

A

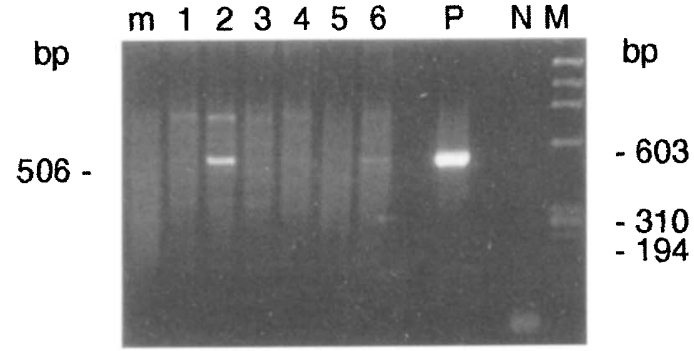

B

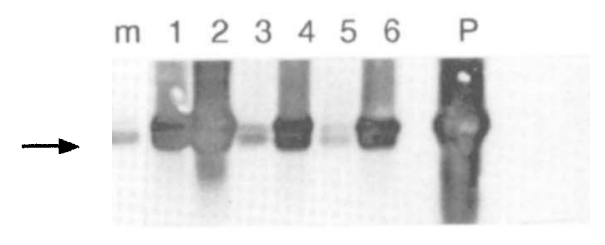

II

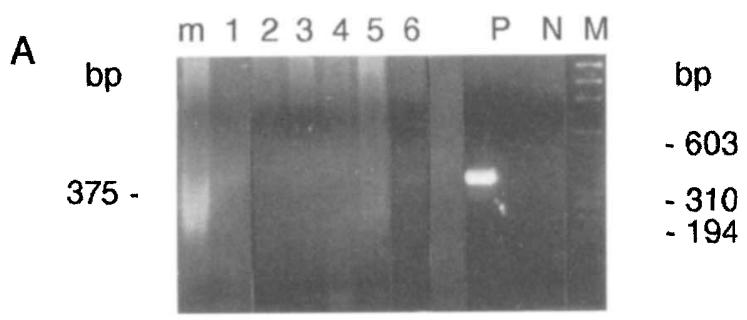

B

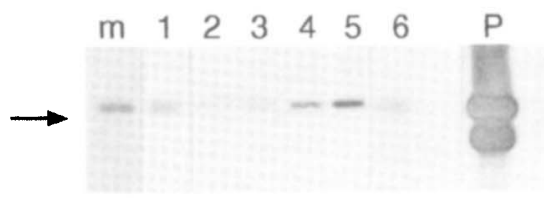

Fig. 1. Representative PCR amplifications applied to cat gastric biopsy samples. I, 16S rRNA RT-PCR; II, hpa APCR. A, Agarose gel electrophoresis; B, corresponding Southern blot hybridisation. DNA extracts from six gastric biopsy samples, obtained from six cat stomachs, were used for amplification. Lane $\mathbf{m}$, represents a whole stomach biopsy obtained from a mouse infected with $H$. heilmannii; P, $10 \mathrm{ng}$ of $H$. pylori (RD26 strain) DNA/ reaction; $\mathbf{N}$, lysis buffer only (negative control); $\mathbf{M}$, Hae III-digested $\Phi$-X174 marker. Arrows indicate the expected position of the amplified product (506 bp for I and $375 \mathrm{bp}$ for II) and the numbers to the right indicate molecular size in bp.

animal models, several Helicobacter species have been discovered and each one has been found to naturally colonise a specific animal host. For example, the natural hosts of $H$. felis, $H$. mustelae, $H$. muridarum, $H$. nemestrinae and $H$. acinonyx are cats and dogs [26, 27], ferrets [28], rodents (rats and mice) [29], primates and cheetahs $[30,31]$.

Although some experimental animals, such as piglets, dogs and mice, have been infected successfully with H. pylori, H. pylori does not naturally colonise the stomach of non-primate animals [32-34]. Hence, until recently, zoonotic transmission has not been considered as a risk factor in the epidemiology of $H$. pylori infection in man. The recent isolation of $H$. pylori 
from a colony of domestic cats $[15,16,26]$ suggested the possibility of zoonotic transmission because of human exposure to cats. Although in this communication, $H$. felis-like organisms and presumably $H$. heilmannii were found in stray cats, $H$. pylori infection was not identified. Recently, the hpaA-PCR assay was shown to amplify same size fragments (375 bp) from $H$. pylori [8], $H$. nemestrinae and $H$. acinonyx [35], and now $H$. heilmannii (from the infected mouse stomach). The Helicobacter organisms identified in the samples by $h p a A$ specific-PCR were not cultivable and were probably $H$. heilmannii or another uncultivable Helicobacter species. The results of the present study agree with previous studies, indicating that $H$. heilmannii is responsible for causing chronic gastritis in cats [36] and with studies reporting on the isolation of different Helicobacterlike organisms, but not $H$. pylori, from cats $[27,29,37-39]$.

The report of the isolation of $H$. pylori from cats obtained from commercial vendors may represent a special circumstance. This is consistent with previous studies showing that owning pets was not associated with an increased prevalence of $H$. pylori infection $[13,40,41]$. Recently, it has been confirmed that owning cats is not associated with an increased risk of acquiring $H$. pylori infection $[42,43]$. While $H$. pylori infection is unlikely to be a zoonosis, infection in cats may represent an anthroponosis.

We thank A. Lee (University of New South Wales, Sydney, Australia) for providing the infected mouse stomach. This work was supported by the Department of Veterans Affairs, the Tom and Pat Powers Foundation and Hilda Schwartz.

\section{References}

1. Graham DY, Go MF. Helicobacter pylori: current status. Gastroenterology 1993; 105: 279-282.

2. Thomas JE, Gibson GR, Darboe MK, Dale A, Weaver LT. Isolation of Helicobacter pylori from human faeces. Lancet 1992; 340: 1194-1195.

3. van Zwet AA, Thijs JC, Kooistra-Smid AM, Schirm J, Snijder JAM. Use of PCR with feces for detection of Helicobacter pylori infections in patients. J Clin Microbiol 1994; 32: 13461348.

4. Shimada $\mathrm{T}$, Ogura $\mathrm{K}$, Ota $\mathrm{S}$ et al. Identification of Helicobacter pylori in gastric specimens, gastric juice, saliva, and faeces of Japanese patients. Lancet 1994; 343: 1636-1637.

5. Kelly SM, Pitcher MCL, Farmery SM, Gibson GR. Isolation of Helicobacter pylori from feces of patients with dyspepsia in the United Kingdom. Gastroenterology 1994; 107: 1671-1674.

6. Nguyen A-MH, Engstrand L, Genta RM, Graham DY, ElZaatari FAK. Detection of Helicobacter pylori in dental plaque by reverse transcription-polymerase chain reaction. $J$ Clin Microbiol 1993; 31: 783-787.

7. Nguyen A-MH, El-Zaatari FAK, Graham DY. Helicobacter pylori and the oral cavity. A critical review of the literature. Oral Surg Oral Med Oral Pathol Oral Radiol Enclod 1995; 79: $705-709$.

8. Hulten K, Han SW, Enroth $\mathrm{H}$ et al. Helicobacter pylori in the drinking water in Peru. Gastroenterology 1996; 110: 10311035 .

9. Vincent P. Transmission and acquisition of Helicobacter pylori: evidences and hypothesis. Biomed Pharmacother 1995; 49: $11-18$.
10. Lee A, Fox JG, Otto G, Hegedus Dick E, Krakowka S. Transmission of Helicobacter spp. A challenge to the dogma of faecal-oral spread. Epidemiol Infect 1991; 107: 99-109.

11. Klein PD, Graham DY, Gaillour A, Opekun AR, Smith EO. Water source as risk factor for Helicobacter pylori infection in Peruvian children. Gastrointestinal Physiology Working Group. Lancet 1991; 337: 1503-1506.

12. Graham DY, Malaty HM, Evans DG, Evans DJ, Klein PD, Adam E. Epidemiology of Helicobacter pylori in an asymptomatic population in the United States. Gastroenterology 1991; 100: $1495-1501$.

13. Graham DY, Lew GM, Klein PD et al. Effect of treatment of Helicobacter pylori infection on the long-term recurrence of gastric or duodenal ulcers. A randomized, controlled study. Ann Intern Med 1992; 116: 705-708.

14. Hopkins RJ, Vial PA, Ferreccio $\mathrm{C}$ et al. Seroprevalence of Helicobacter pylori in Chile: vegetables may serve as one route of transmission. J Infect Dis 1993; 168: 222-226.

15. Handt LK, Fox JG, Dewhirst FE et al. Helicobacter pylori isolated from the domestic cat: Public health implications. Infect Immun 1994; 62: 2367-2374.

16. Handt LK, Fox JG, Stalis IH et al. Characterization of feline Helicobacter pylori strains and associated gastritis in a colony of domestic cats. J Clin Microbiol 1995; 33: 2280-2289.

17. Han SW, Flamm R, Hachem CY et al. Transport and storage of Helicobacter pylori from gastric mucosal biopsies and clinical isolates. Eur J Clin Microbiol Infect Dis 1995; 14: 349-352.

18. Hachem CY, Clarridge JE, Reddy $\mathrm{R}$ et al. Antimicrobial susceptibility testing of Helicobacter pylori: comparison of $\mathrm{E}$ test, broth microdilution, and disk diffusion for ampicillin, clarithromycin, and metronidazole. Diagn Microbiol Infect Dis 1996; 24: 37-41.

19. Roberts GD, Koneman EW, Kim YK. Mycobacterium. In: Manual of clinical microbiology, 5th edn. Balows A, Hausler WJ, Herrmann KL, Isenberg HD, Shadomy HJ (eds) Washington, DC, American Society for Microbiology. 1991: 304-339.

20. Engstrand L, Nguyen A-MH, Graham DY, El-Zaatari FAK. Reverse transcription and polymerase chain reaction amplification of rRNA for the detection of Helicobacter species. $J$ Clin Microbiol 1992; 30: 2295-2301.

21. Evans DG, Karjalainen TK, Evans DJ, Graham DY, Lee C-H. Cloning, nucleotide sequence, and expression of a gene encoding an adhesin subunit protein of Helicobacter pylori. J Bacteriol 1993; 175: 674-683.

22. El-Zaatari FAK, Nguyen A-MH, Genta RM, Klein PD, Graham DY. Determination of Helicobacter pylori status by reverse transcription-polymerase chain reaction. Comparison with urea breath test. Dig Dis Sci 1995; 40: 109-113.

23. Wotherspoon AC, Ortiz-Hidalgo C, Falzon MR, Isaacson PG. Helicobacter pylori-associated gastritis and primary B-cell gastric lymphoma. Lancet 1991; 338: 1175-1176.

24. Wotherspoon AC, Doglioni C, Diss TC et al. Regression of primary low-grade B-cell gastric lymphoma of mucosaassociated lymphoid tissue type after eradication of Helicobacter pylori. Lancet 1993; 342: 575-577.

25. Roggero E, Zucca E, Pinotti G et al. Eradication of Helicobacter pylori infection in primary low-grade gastric lymphoma of mucosa-associated lymphoid tissue. Ann Intern Med 1995; 122: 767-769.

26. Fox JG, Batchelder M, Marini R et al. Helicobacter pyloriinduced gastritis in the domestic cat. Infect Immun 1995; 63: 2674-2681

27. Geyer C, Colbatzky F, Lechner J, Hermanns W. Occurrence of spiral-shaped bacteria in gastric biopsies of dogs and cats. Vet Rec 1993; 133: 18-19.

28. Fox JG, Correa P, Taylor NS et al. Helicobacter mustelaeassociated gastritis in ferrets. An animal model of Helicobacter pylori gastritis in humans. Gastroenterology 1990; 99: 352-361.

29. Lee A, Phillips MW, O'Rourke JL et al. Helicobacter muridarum sp. nov., a microaerophilic helical bacterium with a novel ultrastructure isolated from the intestinal mucosa of rodents. Int J Syst Bacteriol 1992; 42: 27-36.

30. Bronsdon MA, Goodwin CS, Sly LI, Chilvers T, Schoenknecht FD. Helicobacter nemestrinae sp. nov., a spiral bacterium in the stomach of a pigtailed macaque (Macaca nemestrina). Int $J$ Syst Bacteriol 1991; 41: 148-153. 
31. Eaton KA, Dewhirst FE, Radin MJ et al. Helicobacter acinonyx sp. nov., isolated from cheetahs with gastritis. Int $J$ Syst Bacteriol 1993; 43: 99-106.

32. Engstrand L, Gustavsson S, Jörgensen A, Schwan A, Scheynius A. Inoculation of barrier-born pigs with Helicobacter pylori: a useful animal model for gastritis type B. Infect Immun 1990; 58: $1763-1768$.

33. Karita M, Kouchiyama T, Okita K, Nakazawa T. New small animal model for human gastric Helicobacter pylori infection: success in both nude and euthymic mice. Am J Gastroenterol 1991; 86: 1596-1603.

34. Radin MJ, Eaton KA, Krakowka S et al. Helicobacter pylori gastric infection in gnotobiotic beagle dogs. Infect Immun 1990; 58: 2606-2612.

35. Evans DG, Lampert HC, Nakano $\mathrm{H}$ et al. Genetic evidence for host specificity in the adhesin-encoding genes hxaA of Helicobacter acinonyx, hnaA of $H$. nemestrianae and hpaA of $H$. pylori. Gene 1995; 163: 97-102.

36. Feinstein RE, Olsson E. Chronic gastroenterocolitis in nine cats. J Vet Diagn Invest 1992; 4: 293-298.

37. Lee A, Hazell SL, O'Rourke J, Kouprach S. Isolation of a spiral-shaped bacterium from the cat stomach. Infect Immun 1988; 56: 2843-2850.

38. Lavelle JP, Landas S, Mitros FA, Conklin JL. Acute gastritis associated with spiral organisms from cats. Dig Dis Sci 1994; 39: $744-750$.

39. Otto G, Hazell SH, Fox JG et al. Animal and public health implications of gastric colonization of cats by helicobacter-like organisms. J Clin Microbiol 1994; 32: 1043-1049.

40. Fiedorek SC, Malaty HM, Evans DL et al. Factors influencing the epidemiology of Helicobacter pylori infection in children. Pediatrics 1991; 88: 578-582.

41. Webb PM, Knight $\mathrm{T}$, Greaves $\mathrm{S}$ et al. Relation between infection with Helicobacter pylori and living conditions in childhood: evidence for person to person transmission in early life. $B M J$ 1994; 308: 750-753.

42. Ansorg R, Heintschel-van Heinegg E, von Recklinghausen G. Cat owners' risk of acquiring a Helicobacter pylori infection. Zentralbl Bakteriol 1995; 283: 122-126.

43. Webb PM, Knight T, Elder JB, Newell DG, Forman D. Is Helicobacter pylori transmitted from cats to humans? Helicobacter 1996; 2: 79-81. 